\title{
Study Etnografi pada Proses Penetapan Harga Belis di Rote Ndao
}

\author{
Viktor Maria Akbar Soratomo Tukan ${ }^{1}$ \\ Fakultas Ekonomi dan Bisnis \\ Universitas Airlangga, Indonesia
}

\author{
Tjiptohadi Sawarjuwono ${ }^{2}$ \\ Fakultas Ekonomi dan Bisnis \\ Universitas Airlangga, Indonesia
}

\begin{abstract}
Surel : viktorakbar@gmail.com
\section{ABSTRAK}

Tujuan penelitian ini adalah mengungkap proses penetapan harga belis di kabupaten Rote Ndao dan makna harga dari tradisi belis. penelitian ini menggunakan pendekatan teori selfesteem Rosenberg. Penelitian ini merupakan kualitataif dengan menggunakan pendekatan etnografi, Penelitian ini juga menggunakan data yang didapat dari hasil wawancara dan observasi. Hasil penelitian ini menunjukan bahwa proses penetapan harga belis berbeda dengan proses penetapan harga akuntansi, karena terdapat berbagai faktor yang berbeda. Peneliti menemukan empat makna harga. Pertama, harga sebagai bentuk penghargaan. Kedua, harga adalah bentuk ikatan. Ketiga, harga adalah bentuk ucapan terima kasih. Keempat, harga adalah bentuk harga jual wanita. Harga tidak selalu dilihat berdasarkan materi dan angka. Harga memiliki makna yang berbeda dilihat dari sudut pandang masyarakat Rote Ndao.
\end{abstract}

Kata Kunci: $\quad$ Belis; Penetapan Harga; Makna Harga; Etnografi.

\section{Ethnographic Study in the Process of Belis Pricing in Rote Ndao}

\section{ABSTRACT}

The purpose of this study is to uncover the process of determining the price of belis in Rote Ndao and the meaning of the price of the belis tradition. This research uses Rosenberg's self-esteem theory approach. This research is qualitative using an ethnographic approach. This study also uses data obtained from interviews and observations. The results of this study indicate that the price-setting process is not different from the accounting price-setting process, because there are a variety of different factors. Researchers find four meanings of price. First, price as a form of appreciation. Second, price is a form of bonding. Third, price is a form of thanks. Fourth, price is a form of woman's selling price. Prices are not always seen based on material and numbers. Price has a different meaning from the point of view of the Rote Ndao.

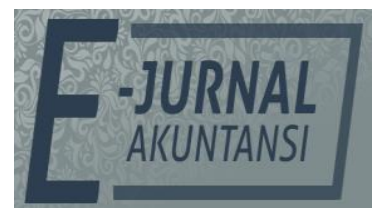

e-ISSN 2302-8556

Vol. 30 No. 9

Denpasar, September 2020 Hal. 2186-2199

DOI:

10.24843/EJA.2020.v30.i09.p02

PENGUTIPAN:

Tukan, V. M. A. S. \&

Sawarjuwono, T. (2020).

Study Etnografi pada Proses

Penetapan Harga Belis di

Rote Ndao. E-Jurnal

Akuntansi, 30(9), 2186-2199

RIWAYAT ARTIKEL: Artikel Masuk: 22 Juli 2020 Artikel Diterima: 24 Agustus 2020

Keywords: $\quad$ Belis; Pricing; Meaning The Price; Ethnography.

Artikel dapat diakses : https://ojs.unud.ac.id/index.php/Akuntansi/index 


\section{PENDAHULUAN}

Keterkaitan antara budaya dan akuntansi bukanlah suatu hal yang baru dan akan selalu menjadi penting, karena akuntasi merupakan bentukan dari budaya yang selalu berkembang. Penelitian antara akuntansi dan budaya itu sendiri sangat banyak berkembang di zaman sekarang ini (Rahayu \& Yudi, 2015), (Rahman, Noholo, \& Santoso, 2019) dan (Randa \& Daromes, 2014). Saat ini pembahasan terkait dengan fenomena akuntansi dalam konteks budaya kemasyarakatan telah cukup banyak diteliti, khususnya dalam budaya perkawinan dengan kata lain disebut dengan istilah "bride pricing". Budaya "bride pricing" atau penetapan harga mas kawin ini telah banyak diteliti dan dibahas serta sangat terkenal di daerah afrika dan asia (Africa \& Asia, 2000), (Mangena \& Ndlovu, 2013) dan (Parikh, 2007). Akan tetapi pembahasan seperti ini masih dianggap sebagai fenomena yang baru dan masih sangat jarang disinggug dalam perkawinan di Indonesia. Dalam penelitian ini peneliti lebih memfokuskan istilah belis yang merupakan metafora dari "bride pricing" di daerah Kabupaten Rote Ndao, Provinsi Nusa Tenggara Timur. Belis dalam artian yang lebih luas merupakan suatu bentuk mas kawin atau mahar, yang diberikan oleh pihak keluarga laki-laki kepada pihak keluarga perempuan, sebagai syarat dalam suatu proses pernikahan, banyak juga yang beranggapan bahwa belis tidak hanya sebagai mas kawin, tetapi juga sebagai suatu bentuk penghargaan terhadap orang tua (Haning, 2006, 2010), dan (Rodliyah, Purwasito, Sudardi, \& Abdullah, 2017).

Budaya belis dalam kaitannya dengan istilah "bride pricing" akan membahas tentang aspek akuntansi yaitu proses penetapan harga. Semuanya ini adalah proses akuntansi yang terjadi akibat hubungan antara setiap orang dalam tatanan masyarakat (Rahayu \& Yudi, 2015) dan (Wuryandini et al., 2018). Banyak hal biasanya berbicara tentang teori sosial kontemporer yang berusaha menganalisis suatu teori dan struktur yang dihasilkan oleh masyarakat. sementara hal yang sama akan menyajikan pandangan individu sebagai produsen realitas sosial (Farahmandian \& Ehsaninia, 2012), (Lowes \& Nunn, 2017), (Mbaye \& Wagner, 2017), dan (Rodliyah et al., 2017). Secara tidak langsung pada proses ini kita akan berbicara tentang penetapan harga belis atau penetapan harga mas kawin pada perkawinan di kabupaten Rote Ndao.

Konsep penetapan harga biasanya di butuhkan dalam proses untuk meraup keuntungan materi semata (Amaliah \& Sugianto, 2018). Keuntungan materi ini merupakan tujuan utama dalam proses penetapan harga, hal ini akan selaras dengan konsep penetapan harga konvensional yang menyatakan bahwa penetapan harga bertujuan untuk mencari keuntungan sebagai tujuan yang utama (Auer, Chaney, \& Sauré, 2017), (Hardesty, Bearden, Haws, \& Kidwell, 2012), dan (Reusen \& Stouthuysen, 2017). Namun dilain hal banyak yang beranggapan bahwa penetapan harga tidak hanya dibentuk dari unsur harga yang berorientasi pada keuntungan semata, sesuai dengan yang telah banyak di temukan pada akuntansi konvensional. Namun pada beberapa unsur harga juga ditentukan dan dibentuk berdasarkan dari nilai-nilai non-material yaitu salah satunya adalah unsur budaya (Amaliah \& Sugianto, 2018), (Ellström \& Larsson, 2017), dan (Raissi \& Tulin, 2018). 
Fenomena yang sangat menarik bagi peneliti adalah muncul anggapan dalam diri kaum muda bahwa belis ini muncul akibat dari kesepakatan penentuan harga. Budaya mas kawin ini bersifat sangat transaksional antara keluarga pria dan keluarga wanita (Rahayu \& Yudi, 2015). Pemahaman masyarakat Rote Ndao dalam tradisi penetapan harga belis menciptakan cara pandang yang berbeda dalam memaknai biaya dan melakukan penetapan harga yang dibayarkan dalam belis, karena terdapat beberapa unsur self-esteem. Artinya, sesuai dengan akuntansi konvensional, harga merupakan suatu interaksi masyarakat antara penjual dan konsumen (Ebere, 2016), (Hardesty et al., 2012), (Malinowski, 2016), dan (Zuryani, 2016), tetapi fenomena yang terjadi, belis memiliki proses penetapan harga sendiri yang sangat berbeda dengan proses penetapan harga di akuntansi, karena terdapat berbagai unsur-unsur yang tiddak bisa di nilai dengan angka. Sesuai dengan fenomena tersebut, peneliti tertarik untuk menganalisis fenomena proses penetapan harga belis budaya perkawinan di kab Rote Ndao?, dan makna harga yang terkandung pada budaya belis sesuai dengan konteks akuntansi?

\section{METODE PENELITIAN}

Penelitian ini menggunakan metode etnografi (Spradley, 1979) yang di jelaskan lebih mendalam oleh (Amri Marzali, 2016). Metode ini sangat baik digunakan bagi etnografer pemula. karena ada lima prinsip untuk memulai metode ini yaitu Pertama, teknik tunggal, peneliti bisa melakukan berbagai teknik penelitian secara bersamaan dengan tidak mengurangi kualitas data informan. Kedua, identifikasi tugas, dalam penelitian proses penetapan harga belis, peneliti pemula akan menfokuskan diri pada dua belas langkah spradley. Ketiga, maju bertahap, peneliti melakukan setiap langkah sesuai urutan, untuk menjaga kualitas data informan. Keempat penelitan orisinil, peneliti akan mempraktekan pada proses penelitian penetapan harga belis di kabupaten Rote. Kelima, Problem solving, peneliti diajarkan untuk menggunakan prinsip bahwa ilmu bukan hanya digunakan untuk ilmu. Tetapi bisa digunakan dalam menyelesaikan masalah di dalam masyarakat.

Beberapa penelitian yang sudah menggunakan etnografi sebagai penelitian adalah (Randa \& Daromes, 2014) dengan karya yang mmenggunakan study etnografi pada gereja katolik untuk menganalisis akuntabilitas spiritual yang terinkulturasi budaya budaya lokal. (Syarifuddin \& Damayanti, 2015) penelitian ini menyikapi tardisi mas kawin sebagai adat istiadat perkawinan Suku yang ada di Makassar, penelitian ini tidak hanya berbicara tentang berbagai gambaran umum temuan peneliti di lapangan, tetapi mengungkapkan dengan penuh keyakinan tentang proses penetapan harga belis dan makna harga apa yang terkandung dalam budaya belis, maka peneliti menggunakan metode etnografi dalam penelitian ini karena sangat sesuai dengan budaya di Indonesia.

Peneliti menggunakan study etnografi karenakan tujuan utama penelitian ini dilakukan pada suatu kebudayaan. Budaya adalah suatu hal yang berhubungan dengan perilaku manusia, seperti penetapan harga belis. Penetapan harga belis di kabupaten Rote Ndao dijelaskan melalui berbagai tahapan yaitu analisis domain, analisis taksonomi dan analisis komponen yang akan digunakan untuk menganalisis dan memahami pertanyaan yang diajukan. 
Karena keterbatasan waktu maka peneliti mencoba memodifikasi 12 langkah (Spradley, 1979), Menjadi 6 langkah Pokok etnografi, tanpa mengurangi dan mengganti hasil analisis data. Enam langkah tersebut adalah; Menentukan informan, wawancara informan, Analisis domain, Analisis taksonomi, Analisis komponen, dan kesimpulan etnografi.

Langkah 1, Menetapkan Informan, semua orang sangat bisa menjadi informan bagi suatu penelitian, namun tidak semua dapat menjadi informan yang baik bagi penelitian. Hubungan informan dan peneliti merupakan ikatan yang sulit untuk dibangun (John, W., \& Creswell, 2016) Oleh sebab itu membangun hubungan yang baik dengan informan merupakan sebuah tantangan yang besar, agar seseorang bisa menjadi informan yang baik.

Informan yang baik memiliki lima persyaratan yaitu 1) enkultulrasi penuh, 2) keterlibatan secara langsung 3) budaya yang peneliti tidak di kenal 4) memiliki cukup waktu dan 5) non analitik (Spradley, 1979) Dari ke lima ketentuan ini maka peneliti memilih lima informan.

Table 1. Data Informan

\begin{tabular}{ll}
\hline \multicolumn{1}{c}{ Informan } & \multicolumn{1}{c}{ Alasan } \\
\hline Tokoh adat & $\begin{array}{l}\text { Informan ini berguna memudahkan peneliti dalam } \\
\text { mengetahui tujuan belis dalam kehidupan bermasyarakat. } \\
\text { Pasangan suami istri dipilih karena merekalah yang dampak } \\
\text { dari tradisi belis ini. }\end{array}$ \\
Keluarga pihak & $\begin{array}{l}\text { keluarga pihak perempuan yang akan menetapkan harga } \\
\text { belis, dan berbagai hal mengenai proses penetapan harga } \\
\text { belis. } \\
\text { keluarga pihak laki-laki yang terkena dampak dari proses } \\
\text { laki }\end{array}$ \\
pentapan harga belis dan terlibat dalam proses tawar- \\
menawi akuntansi
\end{tabular}

Sumber : Data Penelitian, 2020

Langkah 2, Mewawancarai informan. Dalam proses wawancara, peneliti menggunakan pedoman yang bersifat fleksibel, dengan tujuan apabila terjadi perubahan data ketika proses wawancara yang terjadi di lapangan. Fleksibilitas akan berfokus pada tujuan penelitian, yaitu proses penetapan harga belis dan makna harga apa yang terkandung dalam penetapan harga belis dalam konteks akuntansi. Dalam hal ini peneliti menggabungkan tiga tipe pertanyaan wawancara yaitu pertanyan deskriptif, structural dan kontras dalam satu kali kesmpatan wawancara.

Langkah 3, Membuat analisis domain, berbagai kebudayaan memiliki banyak istilah dan banyak istilah yang belum diketahui peneliti, maka peneliti harus membuat analisis domain yang bersumber dari persepsi dan pendapat wawancara, semua ini sangat dibutuhkan untuk mengetahui berbagai istilah local pada proses penetapan harga belis. Hal ini berguna juga dalam menjelaskan istilah masyarakat ketika memaknai suatu proses penentuan harga belis dalam sebuah perkawinan.

Langkah 4, Membuat analisis taksonomik, peneliti diharapkan melakukan analisis lebih jauh terhadap hasil analisis domain. Peneliti harus menambahkan beberapa tambahan informasi dari berbagai sumber dokumen 
seperti dokumen dari perpustakaan daerah, dan foto dari proses penetapan harga belis. Semua itu dapat dijadikan sebagai referensi bagi peneliti dalam menjawab berbagai masalah makna proses penetapan harga belis dalam konteks akuntansi.

Langkah 5, Membuat analisis komponen, tahap ini merupakan keseluruhan proses mencari informasi, pemlihan informasi, pengelompokan informasi dan memasukan informasi ke bagian dari suatu paradigma. Analisis berguna dalam pola pembuktian informasi pada informan dan juga melengkapi semua informasi yang dirasa masih kurang. Pada tahapan akan dilakukan penyederhanaan proses penelitian etnografi dari awal hingga akhir penelitian (Stanley, 2017). Hal ini berguna bagi peneliti untuk mempermudah dalam menarik suatu kesimpulan.

Langkah 6, Kesimpulan etnografi peneliti, melakukan penyusunan laporan dengan menggunakan metode etnografi. Semua laporan yang di tulis akan di sampaikan berdsarkan keadaan yang sebenarnya dengan tujuan agar dapat mengetahui proses penetapan harga belis dan makna apa yang terkandung dalam proses penetapan harga belis sesuai dengan konteks akuntansi.

\section{HASIL DAN PEMBAHASAN}

Pada 15 abad lalu penduduk pulau rote belum mengenal budaya masak, dan mereka memakan masakan mentah. Kemudian mereka mulai mengenal api dengan cara menggesek-gesek dua potong kayu kering. Tetapi seiring berjalan waktu masyarakat rote tidak suka dengan teknologi ini karena sangat sulit digunakan ketika musim penghujan. Masyarakat rote sendiri dibagi menjadi dua yakni penduduk darat dan penduduk laut, penduduk laut memiliki teknologi masak yang sangat canggih yaitu dengan menggunakan besi dan batu api, maka timbulah kenginginan penduduk darat untuk menyerang penduduk laut untuk merampas teknologi tersebut. Salah satu jalan untuk menghindari perang raja dari penduduk laut mulai menjalin kerjasama dengan cara meminang anak gadis dari kerajaan darat, pada saat itu juga mulailah raja dari penduduk darat mengubah rencana pertempuran yakni dengan cara meminta besi dan batu api sebagai belis atau mas kawin bagi anaknya (Haning, 2010)

Di Rote Ndao biasanya besarnya belis tidak sama setiap tingkat sosialnya, karena telah terjadi banyak pergesaran budaya, sehingga adat istiadat yang sekarang ini bersifat lebih dinamis sesuai dengan perkembangan social ekonomi. hal ini sesuai dengan yang dibicarakan oleh tokoh Rote Ndao yang mengatakan bahwa,

"sekarang semua berubah, dulu orang melihat tingkat turunan anak tersebut, sakarang orang lebih melihat dari tingkat pendidikan anak tersebut, SD, SMP, SMA. Pada akhirnya belis yang diminta akan sangat tinggi, karena pendidikan sangat menentukan harga" (Nani, 2020).

Semua ini membuktikan bahwa banyak sekali pergeseran budaya yang secara dinamis berubah seiiring perkembangan zaman. Dahulu masyarakat rote Ndao melihat besarnya belis berdasarkan strata sosialnya tetapi sekarang terjadi banyak pergeseran, karena masyarakat Rote Ndao menentukan harga berdsarkan tingginya tingkat pendidikan dan faktor-faktor lainya. 
Di Rote Ndao tradisi belis ini biasanya menjadi tradisi yang sangat menakutkan, karena masyarakat beranggapanbahwa belis yang terlampau tinggi ini akan menimbulkan beban yang besar bagi anak ketika berumah tangga, karena belis yang besar akan di tanggung oleh keluarga besar, yang harus dikembalikan dan diganti. Hal ini sesuai dengan apa yang dikatakan tokoh masyarakat Adat Rote Ndao bahwa,

"janganlah kita memakai adat-adat yang dulu, karena adat istiadat yang dulu seringkali membuat orang tambah susah, susahnya karena pada akhirnya banyak hutang yang harus bayarkan anak tersebut ketika berumah tangga" (Mesak, 2020).

Beban adat ini adalah hutang yang suami istri tersebut harus lunasi kepada pihak keluarga besar, karena sudah membantunya menikah, sehingga adat menjadi sangat menakutkan.

Belis di Rote Ndao berbeda setiap daerah, di beberapa daerah besarnya belis dibagi menjadi beberapa golongan yakni, belis pihak bangsawan, belis pihak bangsawan fetor, belis kepala suku yang memerintah, belis pihak orang kaya dan belis rakyat jelata (Haning, 2006, 2010).

Belis yang sebanarnya adalah belis yang tanpa tawar-menawar dan terdapat penyerahan balasan dari pihak perempuan, yang besarnya sesuai dengan harga belis atau lebih dari belis yang diminta, oleh sebab itu pihak perempuan sebaiknya mengukur kemampuannya sendiri dalam meminta belis. Karena sebenarnya belis sendiri biasa dijadikan alat untuk mencari keuntungan materi semata. bapak Josef selaku keluarga pihak laki-laki pernah berkata bahwa,

"Ada sebagian orang, yang melihat ini sebagai kegiatan ekonomi, jadi ada yang mencari keuntungan dari belis ini. sehingga oarng itu berusaha supaya belisnya itu tinggi tapi balasannya itu sedikit dan tidak sepadan" (Josef, 2020).

Proses penatapan harga akuntansi meiliki maksud dan tujuan utama adalah keuntungan. Fakta yang terjadi di masyarakat mengatakan bahwa konsep penetapan harga selalu identik dan mimiliki tujuan utama yakni memperoleh keuntungan materi semata, sehingga konsep penetapan harga sangat jauh dari pandangan non-materi (Rahman et al., 2019). Tetapi dalam proses penetaan harga belis masyarakat Rote Ndao tidak memandang hal ini sebagai ajang mencari keuntungan, seperti yang dikatakan oleh ibu tuti seorang dosen akuntansi yang mengatakan bahwa,

"proses penetapan harga dalam akuntansi konvensional dengan budaya belis terdapat beberapa aspek yang sama. Saya dapat mengatakan bahwa bahan baku sesuai dengan wanita itu sendiri, tenaga kerja, adalah proses yang dilalui wanita tersebut sampai menikah. Tetapi penetapan harga dalam akuntansi konvemsional memiliki pertimbangan akhir yaitu keuntungan dan laba, yang didapatkan ketika produk tersebut terjual. sedangkan belis tidak memandang apa itu keuntungan" (Tuti, 2020).

Pernyataan ini menjelaskan bahwa proses penetapan harga memilliki tujuan akhir adalah keuntungan tetapi belis memiliki proses penetapan harga sendiri yang yang berbeda dengan akuntansi konvensional dan tidak memiliki tujuan akhir keuntungan. 
Belis Rote Ndao biasanya merupakan unsur jual dan beli antara pihak wanita kepada pihak laki-laki yang akan disalah artikan oleh masyarakat, masyarakat Rote sendiri beranggapan bahwa unsur jual beli tersebut merupakan suatu bentuk penghargaan dan bentuk terima kasih, tanpa bermaksud mencari keuntungan (Haning, 2010). Dalam beberapa waktu terakhir ini penetapan harga merupakan bentuk utama dari perilaku dan sifat dari harga, semua ini dimaksudkan bahwa proses penetapan harga sangat diharuskan memiliki pertimbangan yang mendalam dan teliti untuk memperoleh harga yang selars dengan kebutuhan dan tujuan (Syarifuddin \& Damayanti, 2015). Harga adalah keputusan yang penuh pertimbangan, karena terdapat beberapa faktor yang mempengaruhi penetapan harga, faktor tersebut adalah faktor yang mempengaruhi secara langsung (intern) dan faktor yang dipengaruhi oleh keadaaan dari luar (ekstern), seringkali faktor tersebut berupa perekonomian, penawaran, biaya, dan tujuan akhir (Syarifuddin \& Damayanti, 2015). Proses penetapan harga belis secara keseluruhan sangat berbeda dengan penetapan harga akuntansi konvensional, karena proses penetapan harga belis ditentukan oleh faktor yang tidak dapat dihitung menggunakan angka dan tujuan dari belis itu adalah tidak untuk mencari keuntungan.

Proses penetapan harga belis seringkali melalui beberapa tahapan yang sangat panjang, penetapan harga belis sendiri memiliki berbagai faktor materi dan immateri antara lain strata social, pendidikan, lingkungan social, harga diri (Self-esteem), dan ketidaksukaan serta belis ibu. Hal ini pernah dikatakan oleh ibu restha bahwa,

"Proses penetapan harga belis itu ditetapkan melalui perundingan antara keluarga dari ibu dan keluarga dari bapak, hasil dari perundingan akan menghasilkan: biaya air susu mama, biaya uang to'o dan jumlah hewan yang diminta. Semua ini ditentukan berdasarkan pendidikan, marga yang digunakan anak tersebut, dan apakah anak tersebut adalah keturunan raja" (Restha, 2020).

Dalam wawancara akan diketahui faktor penentu harga belis, dan biaya lain yang terdapat di dalam belis, hal akan sesuai dengan wawancara dengan bapak Josef sebagai orang tua yang menikahkan anaknya,

"Proses penetapan harga belis biasanya ditentukan berdasarkan ketokohan dari orang tersebut (status social), semakin tinggi status sosialnya, belisnya juga akan semakin tinggi, tingkat pendidikan biasanya dilihat berdasarkan selruh biaya anaknya ketika sekolah, lingkungan social berupa harga diri dan gengsi (kekayaan). biasanya masyarakat akan melihat harta kekayaan seseorang sehingga apabila belis yang diminta tinggi maka harga diri akan tinggi" (Josef, 2020).

Berdasarkan hasil wawancara ini terdapat berbagai faktor immateri yang terkandung dalam proses penetapan harga belis, oleh karena itu sulit untuk menentukan harga belis berdasarkan proses penentuan harga akuntansi konvensional.

Di zaman modern seperti sekarang ini, telah terjadi pergeseran budaya, proses penentuan harga belis sekarang ditentukan berdasasarkan berbagai faktoryakni, faktor strata social, pendidikan, lingkungan social dan harga diri (self- esteem) (Josef, 2020), ada yang menentukan harga belis dilihat dari rasa ketidak sukaan terhadap anak dari kelurga pihak laki-laki (Mesak, 2020) dan ada juga yang menentukan besarnya belis sesuai ketika mamanya menikah dulu 
(Nani, 2020), hal ini jelas sangat berbeda dengan faktor penetapan harga di dalam akuntansi yang biasanya dilihat berdsarkan biaya-biaya yang dikeluarkan, jelas berbeda dengan yang ada pada belis dimana ini semua sangat sulit untuk dijelaskan dengan angka-angka.

Faktor Strata Sosial, proses pnentuan harga belis biasnya sangat ditentukan oleh faktor strata sosial, dalam adat istiadat di Rote Ndao masih menggunakan tingkatan strata social yang terdiri dari pihak bangsawan raja, pihak fetor, pihak kepala suku,pihak orang kaya, dan rakyat jelata (Haning, 2010). Terdapat pula tingkatan strata social yang terdiri dari pihak raja atau anak raja serta cucu raja, mantan raja yang pernah berkuasa, temukung, satu marga, dan rakyat biasa (Khairunnisa, Nur, Leksani, Messah, \& Roosihermiatie, 2014). Tradisi belis adalah tradisi yang dilakukan secara turun temurun dan tidak diketahui pasti kapan Tradisi belis mulai dilakukan, dengan berbagai tingkatan kerajaan, ada raja asli dan pihak fetor dan lain-lain, semua ini sudah dilaksanakan dari zaman dahulu (Mesak, 2020).

Faktor Pendidikan, pendidikan merupakan faktor yang biasa digunakan dalam proses penentuan harga belis, karena kebanyakan orang sudah pergi merantau di kota besar sehingga patokan mereka adalah tingkatan pendidikan, keluarga wanita dapat meminta belis yang sangat tinggi apabila tingkatan pendidikan anaknya tinggi,hal ini sesuai dengan apa yang dikatakan tokoh adat Rote Ndao yakni, orang tua masa kini sudah jarang melihat struktur social sebagai faktor utama, karena banyak orang tua sudah keluar dari kampungnya dalam waktu yang sangat lama, sehingga banyak orang tua melihat tingkat pendidikan dari anaknya (Nani, 2020).

Faktor Lingkungan Sosial, lingkungan social adalah faktor yang biasa digunakan pada proses penetapan harga belis, lingkungan social biasa didapat karena seseorang memiliki pengaruh dan kekayaan di daerah tertentu, ada juga penetapan harga belis menggunakan ketokohan atau pengaruh seseorang, apabila belis seseorang tinggi maka otomatis status social orang tersebut akan tinggi (Josef, 2020). Ketokohan seringkali dilihat dari marga yang ada pada keluarga atau anak perempuan.

Faktor Harga Diri (self-esteem), Harga diri adalah faktor yang penentuan harga belis, harga diri merupakan faktor utama pembentuk faktor-faktor lainya, harga diri akan dibentuk oleh faktor lain misalnya strata social, pendidikan dan lingkungan social. Dalam artian lainnya dalam teori self-esteem Rosenberg, bahwa self-esteem adalah suatu evaluasi positif ataupun negatif yang berhubungan dengan sesuatu tentang dirinya sendiri, harga diri (self-esteem) sendiri seringkali berhubungan dengan berbagai hal yang bersifat spesifik, seperti pendidikan, interaksi antar individu, penampilan, atau harga diri lainya yang sesuai dengan evaluasi terhadap suatu kelompok, dimana kita terlibat dalam kelompok tersebut seperti keluarga, agama, suku, etnis, dan adat istiadat (Srisayekti \& Setiady, 2015).

Faktor Ketidaksukaan Dan Faktor Belis Ibu, faktor ketidaksukaan, faktor ini merupakan faktor ketidaksukaan keluarga perempuan khuusnya orang tua, terhadap kekasih atau calon suami dari anak mereka (Mesak, 2020) dalam kasus ini pihak keluarga perempuan akan mempersulit keluarga calon suami anaknya. dengan cara menaikan besarnya belils menjadi sangat tinggi, dengan maksud 
supaya pihak laki-laki tidak jadi menikahkan anaknya. Dalam kasus seperti ini juga ketika pihak laki-laki berkeinginan kuat maka biasanya terjadi kehamilan diluar nikah dan pemberian ilegal kepada pihak perempuan (Haning, 2010), dan apabila keluarga pihak laki-laki bersedia membayar besarnya belis tersebut, maka keluarga pihak perempuan akan diberi tangung jawab dengan balasan yang besar juga, tetapi seringkali terjadi kecurangan dimana untuk mencari keuntungan maka balasan yang diterima oleh pihak laki-laki tidak sebanding dengan belis yang diberikan. Faktor berikutnya adalah faktor belis mama, yang dalam artian keluarga pihak perempuan melakukan penentuan harga belis berdsarkan besarnya belis sang ibu ketika dulu dipinang oleh ayahnya (Nani, 2020). Apabila dulu yang diberikan ayahnya besar maka tidak bisa jikalau belis yang diminta untuk anaknya lebih kecil dari belis ibunya, setidaknya sama atau bahkan lebih tinggi.

Faktor tersebut adalah faktor dalam proses penetapan harga belis yang seringkali masyarakat Rote Ndao gunakan ketika menentukan belis seseorang. Kita telah banyak belajar dan mengetahui bahwa proses penetapan harga biasanya mempunyai tujuan untuk memaksimalkan kesejahteraan, hal itu dalam bentuk suatu keuntungan (Wuryandini et al., 2018), sesuai dengan berbagai hal tersebut baiasnya orang tua yang mempunyai anak perempuan bisa menetapkan harga yang sesuai dengan kebutuhannya, sehingga ketika seorang laki-laki datang untuk melamar anak perempuanya, keluarga pihak laki-laki sanggup untuk membayar belis tersebut. karena pihak laki-laki juga melihat dari faktor pengorbanan orang tua untuk membesarkan anaknya, akan tetapi penetapan harga belis yang sangat tinggi akan menggoyahkan kemampuan keluarga pihak laki-laki dan secara kasar beslis akan disalah artikan sebagai alat penukaran wanita, alat perdagangan wanita, karena biasnya harga belis yang tinggi akan menimbulkan berbagai dampak negative (Liva, 2020).

Dalam ilmu akuntansi yang kita pelajari, proses penetapan harga adalah proses penetapan harga yang sesuai dengan keseluruhan biaya yang dikeluarkan ketika melakukan suatu aktivitas (Lucas, 2003) sedangkan proses perhitungan suatu biaya seringkali dihitung dan dilihat berdasarkan biaya bahan baku, biaya sumber daya manusia, biaya overhead, dan biaya lain-lain (Wuryandini et al., 2018). Ketika proses penetapan harga akuntansi konvensional digunakan dalam proses penentuan harga belis akan terjadi kesulitan ketika menghitung berbagai biaya yang telah dikorbankan, karena terdapat beberapa faktor yang tidak dapat dihitung dengan angka-angka.

Proses penetapan harga sendiri membuat keyakinan bahwa teori akuntansi selama ini terbelenggu dan terbentuk berdasarkan nilai-nilai kapitalistik yang selama ini ada dalam dirinya, dimana harga yang adalah bagian dari praktek akuntansi konvensional merupakan suatu ilmu yang terbentuk dari nilai-nilai budaya (Amaliah \& Sugianto, 2018), semua ini menjelaskan bahwa kehidupan masyarakat tidak semuanya bisa menggunakan proses penetapan harga akunatnsi konvensional karena terdaapat juga proses penetapan harga yang berbeda dari proses penetapan harga akuntansi konvensional yakni proses penetapan harga belis.

Makna harga adalah suatu teori yang sangat menarik untuk di teliti lebih lanjut, karena kehidupan manusia pasti akan selalu berhubungan dengan harga. 
Realitas yang ada mengatakan bahwa konsep makna harga dalam akuntansi konvensioanal akan berkaitan langsung dengan motivasi untuk memperoleh keuntungan, dan tujuan utama dari penetapan harga adalah uang (Amaliah \& Sugianto, 2018). Konsep akuntansi yang berbicara tentang harga berbeda dengan makna harga yan terkandung di dalam budaya belis. Belis telah menjadi ketakutan tersendiri bagi masyarakat Rote dan masyarakat lain yang akan menikah dengan orang Rote. Tidak heran ketika kita menjumpai besasrnya belis yang tidak masuk akal, mulai dari puluhan sampai ratusan juta, sehingga makna harga yang terkandung dalam belis itu sebenarnya apa?(Syarifuddin \& Damayanti, 2015).

Dalam akuntansi proses penetapan harga adalah suatu bentuk dari perilaku harga (Lucas, 2003)Dalam proses penetapan harga kita perlu melakukan pertimbangan yang mendalam guna medapatkan makna harga yang sesuai dengan tujuan kita (Syarifuddin \& Damayanti, 2015). Dimana proses tersebut sebaiknya menggunakan faktor-faktor yang mempengaruhi harga tersebut. Berbicara tentang belis dilihat dari ilmu akuntansi, faktor-faktor pembentuk harga belis sebaiknya dipertimbangkan, penetapan harga belis sebaiknya sesuai dengan semua biaya yang dikeluarkan baik untuk menikah ataupun resepsi penikaham yang dikorbankan (Syarifuddin \& Damayanti, 2015). Tanpa perlu melihat faktor strata social, pendidikan, harga diri, dan lingkungan social (Wuryandini et al., 2018), sehingga dapat tercipta makna harga yang cocok dengan tujuan dan kebutuhan utama.

Makna harga pada tradisi belis berbeda dengan makna harga yang ada pada akuntansi konvensioanal. Pemahaman makna harga bagi masyarakat Rote memiliki artian tersendiri dan sangat berbeda dengan akuntansi, hal ini sesuai dengan hasil wawancara tentang makna harga yang sesungguhnya bagi orang Rote Ndao.

Harga sebagai bentuk Penghargaan, belis bagi masyarakat Rote Ndao memilki makna penghargaan yang diberikan pihak laki-laki kepada orang tua perempuan karena telah merawat, menjaga dan membesarkan anak perempuannya dengan baik (Rahayu \& Yudi, 2015) dan (Syarifuddin \& Damayanti, 2015). Semua ini sama dengan hasil wawancara bahwa harga sebagai bentuk penghargaan terhadap seorang wanita dan orang tuanya (Tuti, 2020). Harga merupakan sebuah bentuk penghargaan terhadap orang tua dan ungkapan kasih sayang anak terhadap kasih sayang ibu (Mesak, 2020).

Harga sebagai bentuk ikatan, belis sebagai ikatan antara suami dan istri agar di kemudian hari tidak terjadi perceraian (Nani, 2020). Pernikahan orang Rote Ndao Rote sangat sacral dan tak terpisahkan oleh apapun, orang Rote Ndao memiliki keyakinan bahwa yang telah diberkati oleh Tuhan tidak dapat diceraikan oleh siapapun (Haning, 2010) semua ini membuktikan bahwa pernikahan masyarakat Rote Ndao bersifat tidak bisa diceraikan dan satu sampai mati. Hal ini membuktikan bahwa fungsi harga sebagai pengikat dimana masyarakat Rote Ndao menjadi takut untuk nikah berulang kali, karena harga Belis yang sangat tinggi.

Harga sebagai bentuk terima kasih, Harga belis yang ditentukan biasanya bagi masyarakat Rote Ndao merupakan suatu bentuk ucapan terima kasih. (Restha 2020) ucapan terima kasih ini diberikan dalam bentuk besarnya harga 
belis. Ucapan terima kasih diminta pihak perempuan kepada pihak laki-laki dalam bentuk belis yang tinggi, biasanya ditentukan dari semua biaya yang dikorbankan orang tua untuk mendidik dan membesarkan anaknya. Untuk menekan besarnya harga belis tersebut sebaiknya kita mempunyai pembanding agar harga belis yang ditentukan bisa diturunkan (Josef, 2020).

Harga sebagai jual beli wanita dan alat tukar wanita, makna harga secara tidak langsung sebagai alat tukar wanita, alat jual beli wanita, karena biasanya karena tingginya harga belis yang diminta akan menimbulkan kerenggangan antara keluarga pihak laki-laki dan keluarga pihak perempuan (Liva, 2020) banyak pendapat mengatakan bahwa mas kawin atau semua bentuk pemabayaran perkawinan akan disamakan dengan biaya produktivitas wanita, biaya mertabat wanita dan biaya hak wanita (Cianci, Kaplan, \& Samuels, 2013), (Ebere, 2016), (Hague, Thiara, \& Turner, 2011) dan (Rodliyah et al., 2017). Dalam kasus ini makna harga akan serupa dan sama dengan makna harga pada akuntansi konvensional yang tujuan utamanya adalah mencari keuntungan semata, dimana harga belis dikatakan sebagai alat jual beli wanita dan alat tukar antara pihak laki-laki dan pihak perempuan.

Sebagian masyarakat menilai keseimbangan harga dan biaya menyebabkan banyak sekali pertanyaan yang bermunculan, karena menurut akuntansi biaya yang besar akan menghasilkan laba yang besar. Hal ini yang membuat masyarakat beranggapan bahwa harga akan selalu berpusat pada keuntungan yang didapat, tetapi masyarakat Rote Ndao memiliki pemikiran sendiri yang mengatakan bahwa besarnya belis yang diminta merupakan suatu bentuk penghargaan, ucapan terima kasih dan ikatan. Perspektif mengenai besarnya belis merupakan bentuk penghargaan masyarakat Rote Ndao terhadap unsur kehidupan, pada masa sekarang ini tradisi belis sudah tidak cocok lagi dengan situasi yang ada, karena banyak orang sudah berpikiran maju dan mulai meninggalkan adat-adat lama, tetapi kembali lagi hal ini merupakan sebuah tradisi yang harus selalu dilakukan (Liva, 2020).

\section{SIMPULAN}

Penelitian menyimpulkan bahwa berbicara tentang harga berarti kita berbicara tentang tujuan mencari keuntungan, tujuan utama tersebut bisa didapatkan dengan berbagai pertimbangan biaya misalnya biaya bahan baku, tenaga kerja dan biaya lain-lain. Hal ini sangat berbeda dengan proses penetapan harga belis. Proses penentuan harga belis biasanya melalui tahapan yang panjang dan terkadang rumit. Terdapat berbagai faktor utama pembentuk harga belis yakni Strata social, Pendidikan, Harga diri (self-esteem), Lingkungan social, Ketidaksukaan dan belis mama. Harga memiliki artian yang berbeda jika dilihat dari pandangan masyarakat Rote Ndao. Harga memiliki makna 1). Harga sebagai bentuk Penghargaan, 2). Harga sebagai bentuk ikatan, 3). Harga sebagai bentuk terima kasih , 4). Harga sebagai jual beli wanita. Makna harga memiliki artian yang berbeda apabila dilihat dari sudut pandang yang berbeda, ketika kita berbicara mengenai akuntansi kita tidak bisa hanya terpaku pada nominal dan angkaangka, karena akuntansi lahir dari unsur budaya dan tradisi yang terus berkembang. 
Ketika kita menggunakan proses penetapan harga dalam akuntansi dalam proses penentuan harga belis maka maka yang akan terjadi adalah kesulitan dalam menghitung semua biaya-biaya yang dikorbankan, semua ini sesuai dengan penelitian (Damayanti dan Syariffudin, 2015) yang menjelaskan bahwa uang panaik sebaiknya mengunakan real cost yang ada. karena terdapat berbagai faktor-faktor yang tidak bisa diukur dengan angka-angka, yakni strata social, pendidikan, harga diri, lingkungan social, dan ketidaksukaan serta belis ibu. sebaiknya kita tetap menggunakan proses penentuan harga belis yang telah ada dan diwariskan secara turun-temurun. Apabila ingin memakai proses penentuan harga akuntansi konvensional, maka alangkah baiknya jika segala faktor strata social, pendidikan, harga diri, dan lingkungan social harus dihilangkan, dan kita hanya menggunakan real cost yang akan dikorbankan dalam aktivitas mengadakan pernikahan, misalnya dalam resepsi dan pemberkatan nikah.

\section{REFERENSI}

Africa, I., \& Asia, I. (2000). Bride Price And Domestic Violence Briefing Paper By Kulsum Wakabi , 2000 The Mifumi Project In Partnership With Prompt Introduction: The Global context The Mifumi Bride-Price and Domestic Violence Project Domestic Violence and Bride Price Young Persons A.

Amaliah, T. H., \& Sugianto, S. (2018). Konsep Harga Jual Betawian dalam Bingkai Si Pitung. Jurnal Akuntansi Multiparadigma, 9(1), 20-37. https:// doi.org/10.18202/jamal.2018.04.9002

Amri Marzali. (2016). metode etnografi. (tiara wacana, Ed.) (2nd ed.). yogyakarta.

Auer, R. A., Chaney, T., \& Sauré, P. (2017). Quality Pricing-to- Market, (657).

Cianci, A. M., Kaplan, S. E., \& Samuels, J. A. (2013). The Moderating Effects of the Incentive System and Performance Measure on Managers' and Their Superiors' Expectations about the Manager's Effort, 25(1), 115-134. https:// doi.org/10.2308/ bria-50290

Ebere, C. (2016). Bride Price. Encyclopedia of Family Studies, 1-5. https://doi.org/10.1002/9781119085621.wbefs346

Ellström, D., \& Larsson, M. H. (2017). Dynamic and static pricing in open-book accounting. Qualitative Research in Accounting and Management, 14(1), 21-37. https://doi.org/10.1108/QRAM-09-2015-0071

Farahmandian, H., \& Ehsaninia, S. (2012). Dynamics of tradition and modernity in bride price by buchi emecheta. International Journal of Applied Linguistics and English Literature, 1(4), 191-196. https://doi.org/10.7575/ijalel.v.1n.4p.191

Hague, G., Thiara, R. K., \& Turner, A. (2011). Bride-price and its links to domestic violence and poverty in Uganda: A participatory action research study. Women's Studies International Forum, 34(6), 550-561. https:// doi.org/10.1016/j.wsif.2011.06.008

Haning. (2006). Hukum Kekeluargaan: (Perkawinan \& Waris) Masyarakat. (Karios, Ed.) (1st ed.). rote ndao.

Haning. (2010). Hukum Kekeluargaan: (Perkawinan \& Waris) Masyarakat. (karios, Ed.). rote ndao.

Hardesty, D. M., Bearden, W. O., Haws, K. L., \& Kidwell, B. (2012). Enhancing 
perceptions of price-value associated with price-matching guarantees. Journal of Business Research, 65(8), 1096-1101. https://doi.org/10.1016/j.jbusres.2011.08.024

John, W., \& Creswell, C. N. P. (2016). Qualitative Inquiry and Research Design: Choosing Among Five Approaches, 4(Fourth; H. Salmon, ed), California: Sage publication.

Khairunnisa, M., Nur, I., Leksani, E., Messah, D. L., \& Roosihermiatie, B. (2014). Perempuan Rote Meniti Tradisi.

Lowes, S., \& Nunn, N. (2017). WIDER Working Paper 2017 / 131 Bride price and the well - being of women, (June).

Lucas, M. R. (2003). Pricing decisions and the neoclassical theory of the firm. Management Accounting Research, 14(3), 201-217. https:// doi.org/10.1016/S1044-5005(03)00044-1

Malinowski, A. B. (2016). Wiley, Royal Economic Society, 31(121), 1-16.

Mangena, T., \& Ndlovu, S. (2013). Implications And Complications Of Bride Price Payment Among The Shona And Ndebele Of Zimbabwe Sambulo Ndlovu. International Journal of Asian Social Science, 3(2), 472-481. Retrieved from http://www.aessweb.com/journal-detail.php?id=5007

Mbaye, L. M., \& Wagner, N. (2017). Bride Price and Fertility Decisions: Evidence from Rural Senegal. Journal of Development Studies, 53(6), 891-910. https://doi.org/10.1080/00220388.2016.1208178

Parikh, S. A. (2007). The political economy of marriage and HIV: The ABC approach, "safe" infidelity, and managing moral risk in Uganda. American Journal of Public Health, 97(7), 1198-1208. https:/ / doi.org/10.2105/ AJPH.2006.088682

Rahayu, S., \& Yudi. (2015). Uang Nai': Antara Cinta dan Gengsi. Jurnal Akuntansi Multiparadigma, 6(2), 224-236. https://doi.org/10.18202/jamal.2015.08.6018

Rahman, Y., Noholo, S., \& Santoso, I. R. (2019). Konsep Akuntansi Syariah Dalam Budaya Mahar. Jurnal Akuntansi Multiparadigma, 10(1), 82-101. https://doi.org/10.18202/jamal.2019.04.10005

Raissi, M., \& Tulin, V. (2018). Price and income elasticity of Indian exports - The role of supply-side bottlenecks. Quarterly Review of Economics and Finance, 68, 39-45. https:/ / doi.org/10.1016/j.qref.2017.11.003

Randa, F., \& Daromes, F. E. (2014). Akuntabilitas Organisasi Sektor Publik.

Reusen, E., \& Stouthuysen, K. (2017). Misaligned control: The role of management control system imitation in supply chains. Accounting, Organizations and Society, 61, 22-35. https://doi.org/10.1016/j.aos.2017.08.001

Rodliyah, S., Purwasito, A., Sudardi, B., \& Abdullah, W. (2017). Between Economic Burden and Cultural Dignity: Belis in the Marital Custom of the NTT Society. Komunitas: International Journal of Indonesian Society and Culture, 9(1), 92-103. https:// doi.org/10.15294/komunitas.v9i1.8672

Spradley. (1979). the etnography interview. (belmont, Ed.) (2nd ed.). california: wadsworth publishing company.

Srisayekti, W., \& Setiady, D. A. (2015). Harga-diri (Self-esteem) Terancam dan $\begin{array}{llll}\text { Perilaku Menghindar. Jurnal Psikologi, 42(2), } & 141 .\end{array}$ https://doi.org/10.22146/jpsi.7169 
Stanley, C. (2017). Strategic Cost Management and Performance: The Case of Environmental Costs. Social and Environmental Accountability Journal, 37(2), 150-151. https:/ / doi.org/10.1080/0969160X.2017.1345812

Syarifuddin, \& Damayanti, R. A. (2015). Story of Bride Price: Sebuah Kritik atas Fenomena Uang Panaik Suku Makassar. Jurnal Akuntansi Multiparadigma, (1979). https:// doi.org/10.18202/jamal.2015.04.6007

Wuryandini, A. R., Ekonomi, F., Negeri, U., Husain, S. P., Ekonomi, F., Negeri, U., ... Ledo, S. K. (2018). The real cost of bride price: cintaku tak bertepuk sebelah tangan. Jurnal Wawasan Dan Riset Akuntansi, 6(1), 18-35.

Zuryani, N. (2016). Baliterhadap Praktek Belis Kekinian, 6, 1-13. 